\title{
The Industrial Heritage and the New Architecture: Teaching, Researching, Designing the Place Identity
}

\author{
Monica Bruzzone and Roberta Borghi \\ Department of Civil Engineering and Architecture (DICATEA), University of Parma, Genoa 16142, Italy
}

\begin{abstract}
The new architecture may provide unusual opportunities for the abandoned areas involved by former industrial processes, both in the city centers and in the landscape. In fact, it may create new centralities and give new collective function for deprived areas. The case study of the architectural and educational project for a new museum park devoted to the technique and the science in the Apennine' s landscape near Parma (Italy) may give an interesting point of view about the role of the teaching and the research of the architecture in the former industrial heritage, and to avoid the abandonment and the pauperization of the territory around.
\end{abstract}

Key words: Identity, industrial heritage, architecture, architecture design studio, teaching, research.

\section{Introduction}

The architecture may provide new opportunities for the places development, particularly in those urban or rural landscapes where the end of a productive tradition have established heavy losses, both from a social point of view, with the gradual loss of a local identity - well represented by that specific technique or industry - and from a environmental point of view, with the creation of large urban voids and the presence of a disused industrial heritage, often rich in quality.

In this case study, the new architecture may represent a important way of giving opportunities to a deprived area by introducing new functions or new central points and by giving, as well, a new social identity for the place.

The industrial heritage and the large areas deprived by the abandonment of factories, workshops, mines or pits after the end of the production, may represent at the same time the remains of an ancient technical identity and the opportunity for designing a new identity, giving the territories who hosted the industry a new cultural or productive life, starting from both the physical and immaterial rests of a lost past.

Corresponding author: Monica Bruzzone, Ph.D., research fields: architecture, architectural, design, industrial heritage and places identity. E-mail: monica.bruzzone@unipr.it.
The new architectural design has to consider, therefore, a wide number of variables to produce an effective new architectural project.

First of all, it is necessary to make a deep research about the characteristics of the places and the needs of its community, so to interpret the true values of the old industrial vocation and to understand what memories you have to save and how can you represent them by the new architecture. Then it is necessary to ask which functions can you assign to the site, in order to turn a negative polarity in a new public centrality, where it can be pleasant to live, to work, to study, to attend cultural events or just to "stand and stare". A wrong design process may deliver the place, once again to oblivion and neglect. At the same time, it is important to consider how the research, the teaching and design, may be complementary for rethinking the former industrial heritage and for rediscovering the local identities.

The Research Group AMR/APR [1], working with the Department of Civil Engineering and Architecture (DICATeA), University of Parma, is experiencing since many years how the rural areas and the small towns of the Emilian Appenines may be requalified by a new kind of architecture. As well the main objective of this study is to demonstrate how to contribute to the 
development of a former industrial area by the new functional, social and architectural project, and how a new centrality for the community or, if you want, a new "piazza" may give new values for a wider area, creating new kinds of use for that place.

\section{The Industrial Heritage and the Role of the Architecture}

It is important to note that the main references of these studies can be found in some Italian researches of the 1970s and 1980s and in the definition-or better in the re-definition - of some specific cultural values based on the delicate balance between the work of men and the landscape development [2].

The interpretation of the so called "Italian condition" by the researcher Emilio Sereni, Lucio Gambi and Giulio Bollati [3], aims for instance, at defining new interests for the rural areas as actors of the architectural process as well as the metropolitan areas. A concept already developed in Italy by Giuseppe Pagano [4] just before the Second World War.

The connections between the men's work and the physical characteristics of the territory are also deepened in 1970s by the Italian geographer Lucio Gambi. He clarifies that the relationship between the place and the human's work is an essential goal in the development of any community. The man settles in areas with good characteristics for the life and the production, and then he modifies those places and makes them appropriate for the lifestyle of the community and the techniques of settlement.

As opposed to the Paul Virilio theory of "crepuscular dawn" [5] as a condition of de-territorialisation and loss of cultural reference points, the "sense of place" defined by Gambi [6] may represent an effective tool for the design process in the landscape. As well, the most recent definition of "family relationship between men and land" by Salvatore Settis [7] may be a good starting point for a new way of understanding the relationships between the countryside and the new architecture. The former industrial sites on the Emilian Appenines may be interesting examples of how represent a new heritage to discover, by the creation of new centralities to the development of wider areas.

\subsection{The New Architecture: Tool for the Development of the Former Industrial Sites}

The Research Group "Architecture Museums Networks", is working since many years on the subject of redeveloping little centres and parts of landscape through the insertion (or better you could say the "infill") of a new architectural polarity inside the landscape. The new project may be a public place or a collective building or just a square, but it may have the special skill of interpreting the social needs of the community and creating a new centrality for this specific "horizon of territory" or "unity" of landscape itself. So you aim at building a new identity by the construction of new characters for that specific society starting from the ancient memory of the site. The project is deepened by the collaboration with some important institution for the local heritage such as the IBC (Istituto per i Beni Artistici, Culturali e Naturali), that is the institute for Cultural Heritage of the Region Emilia Romagna, in Italy. Some of this studies became architectural projects or bachelor's thesis by the members of the research group.

\subsection{The Officine Reggiane, Reggio Emilia Italy}

The ancient Officine Meccaniche Reggiane is a former industrial site where, since the first years of the 20 th century there was a wide production of railways components and artillery projectiles. The industry became famous in the late 1930s for the production of the fighter aircrafts. After the end of the production, in the early 1950s, the wide site of the Reggiane became a urban void. The research group aimed firstly with the degree thesis by Roberta Borghi (Fig. 1), at redesigning the whole site of the Reggiane, building a new centrality with services, cultural activities, work 


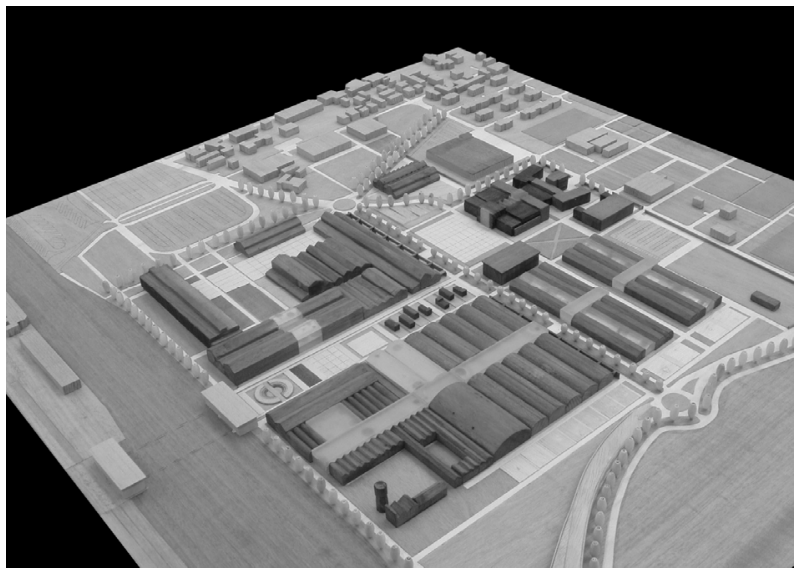

Fig. 1 A model of the Officine Meccaniche Reggiane, design by architect Roberta Borghi, year 2008.

spaces and public spaces for the city of Reggio Emilia. The starting point of the design process was the interpretation of a peculiar ancient axis and streets, designing a museum dedicated to the Officine Meccaniche Reggiane, a way of transmitting the memories of a still strong identity.

\subsection{The Glass Museum and Science Centre Bormioli in Parma}

The "Bormioli Rocco \& Figlio" is one of the oldest glassware in the city of Parma. Around the first workshop, built in 1854, it was created a new neighbourhood inhabited, in the beginning, by the workers families. Now the neighbourhood is a part of the city of Parma, extended further beyond the old perimeter of the nineteenth century. After the end of the production, the ancient factory became a wide urban void in the middle of a residential district of Parma and today it aims at becoming a new centrality for Parma as a polycentric city. The recent proposal by the architect Luca Vacchelli, aim at creating a new cultural polarity to give the area a functional characterization, a kind of specialization. The study for this area is commissioned by the owners: The "Bormioli Rocco" and it will be evaluated by the municipality of Parma.

The Science Centre (Fig. 2) is a missing cultural polarity for Parma, and at the same time the environments of the old factory, with galleries and

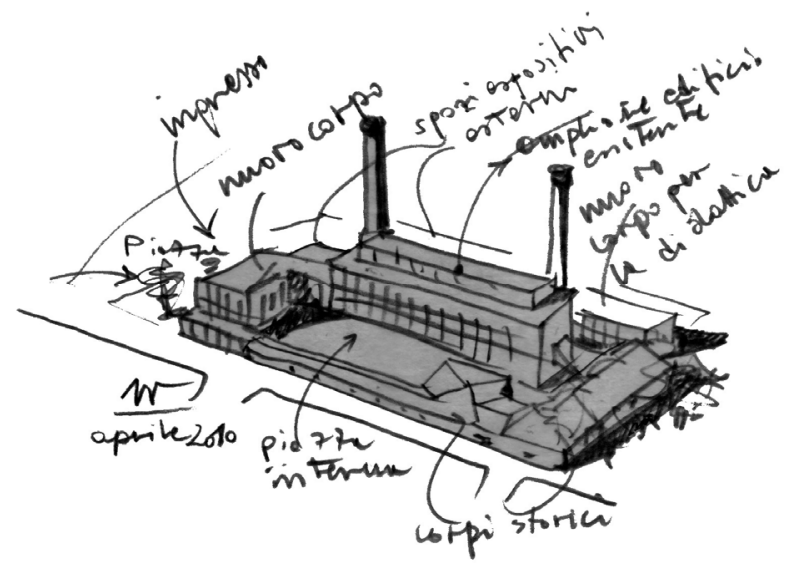

Fig. 2 Sketch of the science center and glass museum Bormioli, design by architect Luca Vacchelli (2010-2012).

long and narrow halls, is very adequate for the needing of a contemporary science centre, with interactive boxes and large-scale reconstructions. As well the older building is dedicated to the Glass Museum Bormioli: a place for the memory of the lost identity of the factory.

\section{The Petroleum Museum Park in Fornovo di Taro, Parma}

The project of a Petroleum Museum Park (Fig. 3) for the little town of Fornovo di Taro, nearby Parma is an important case study where teaching, researching and designing are considered three important parts of a common process. This study is now starting an operating phase after receiving funding by the MIUR, the Italian Ministry of University and Research, based on the annual programs proposed by the Italian Law $6 / 2000$. In this part of the architectural design process, the research group aims at giving new life and new characters to a former industrial site, with a multimedia exhibit and a design of guidance in the park, so the architecture may be the most important

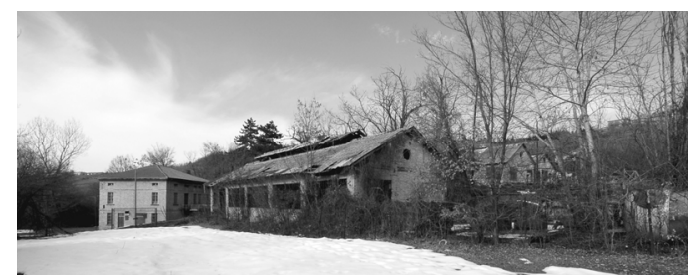

Fig. 3 The workshops and the forge of Vallezza, photo by Andrea Ciampolini ${ }^{\circ}$. 
opportunity for the redevelopment of a wider part of landscape in a pleasant part of the Apennines.

The research program is based on an agreement between the University of Parma, the Municipality of Fornovo and the Oil Company Gas Plus Italiana SpA, owner of the areas. The aim of the research is to recover the industrial and the natural heritage in one of the oldest oilfields in Italy (1860-1970), for both tourist and educational purposes. The mine, developing a local self extractive system called "metodo Fornovo", was intensively exploited in the early 20th, and almost exhausted during the autarkic period of the Fascism, when it was one of the focal points for the supply of crude oil for the army. The mine is also the place where it was established the Società Petrolifera Italiana, now called Ente Nazionale Idrocarburi, one of the most important operators of hydrocarbons in Italy.

Some oil wells and natural gas wells have remained active up to 1970, until the production became uneconomic. Since that time, after the reclaiming of the wells and some industrial plants, the ruins of the workshops, the forge, the power station, the pumping stations in the wood and the miners village, have lost their former function and now they remain as well as rests: objects trouvé immersed in the clay hills of Fornovo. The dissemination of the extraction techniques and the memory of the ancient oilfield, may play an important role in the educational program of the Province of Parma, where there are not museums or study centers devoted to disseminate the sciences and the techniques.

As a verification process of an evolving theoretical subject, the Architecture Design Studio (Second year of the Degree in Architecture) is working on the architectural and urban design of these depressed areas by the introduction of a new architecture as a new public centrality able to give a new identity and new social functions to the place.

The work is divided in two different phases. In the first semester a preliminary approach to the project, is devoted to transmit some cultural issues and some positions of the architectural debate. In the second semester, each student have to apply these notion to a design process connected with the place of the Oilfields of Fornovo di Taro.

In the first part, students have to learn by basis elements of the architectural process as well as the construction and the assembly, the cut or the excavation of solid corps, making exercise of creating a new architectural space by the addition or the subtraction of matter.

This is a way to investigate how the architectural design should begins from theoretical premises and the personal poetry, but it may become architecture only through the "contamination" with the materials and the techniques. The first exercise is the design of a small exhibition pavilion with a dimension of $6 \mathrm{~m} \times 6$ $\mathrm{m} \times 6 \mathrm{~m}$, for the exhibition of an only artwork, as suggested in the literary essay: "The museum in the third millennium" by Eco [8]. The creation of a 1:20 scale maquette of the small building becomes necessary to learn the three-dimensional role of the architectural projects (Fig. 4).

The second exercise is the redrawing of two different existing buildings: an exhibition pavilion and a most complex building chosen between lists of architectural models of 20th century (Fig. 5).

The second semester is focused on the project of a Petroleum Museum Park in the valley of Fornovo,
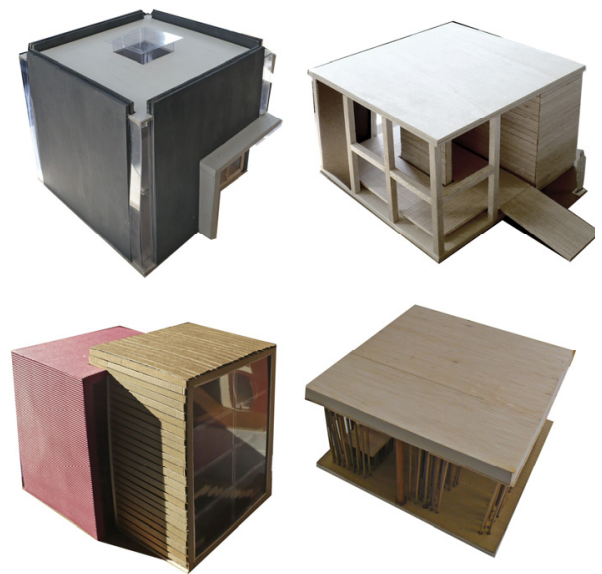

Fig. 4 The architectural models of the first semester. 


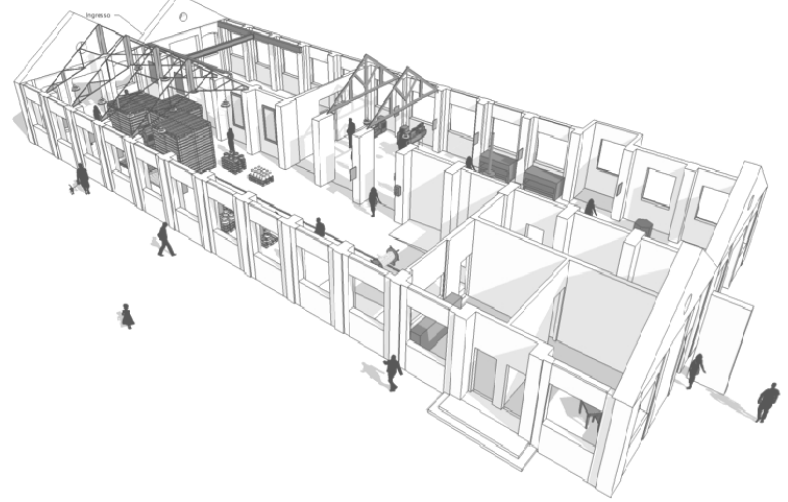

Fig. 5 The oil pavilion: A new exhibitions pavilion for the area of Vallezza.

seat of the ancient oilfield. Students are called to reflect on different scales of the design: from the landscape to the building, up to the exhibition design.

Students are divided in groups of two or three people. Each group is called to design a park museum with the aim of enhancing the place by deepening some specific architectural and functional themes, such as a meeting place for tourists and for the bikers,

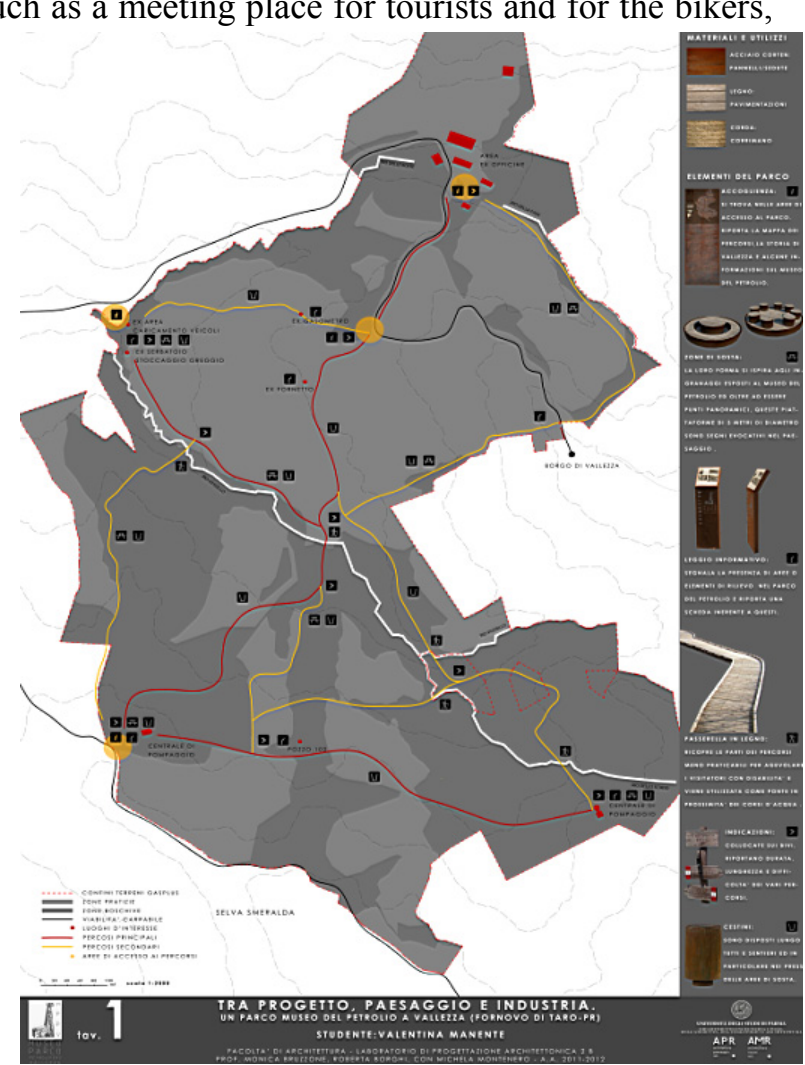

pathways and roots trough the industrial rests, but also a study place for disseminating the identity of the former oilfield (Fig. 6).

After deepening the park, each group may design the new cultural centrality with a museum devoted to the technique and the scientific culture, a study centre with a small auditorium, a library and a laboratory for the children's activity, but also a place for guests, such as a little diffused hotel (in the little town of Vallezza, the former miner's village), or a guesthouse for tourists and schools visiting the place. In the last month of the year each group deep an only building in scale 1:100

This approach to the design process aim at giving the students the special skill of "seismographs" of the needs of the place having a direct approach with inhabitants and better understanding the place's problems.

In parallel with this teaching process, also useful to raise public awareness of, and with funds obtained

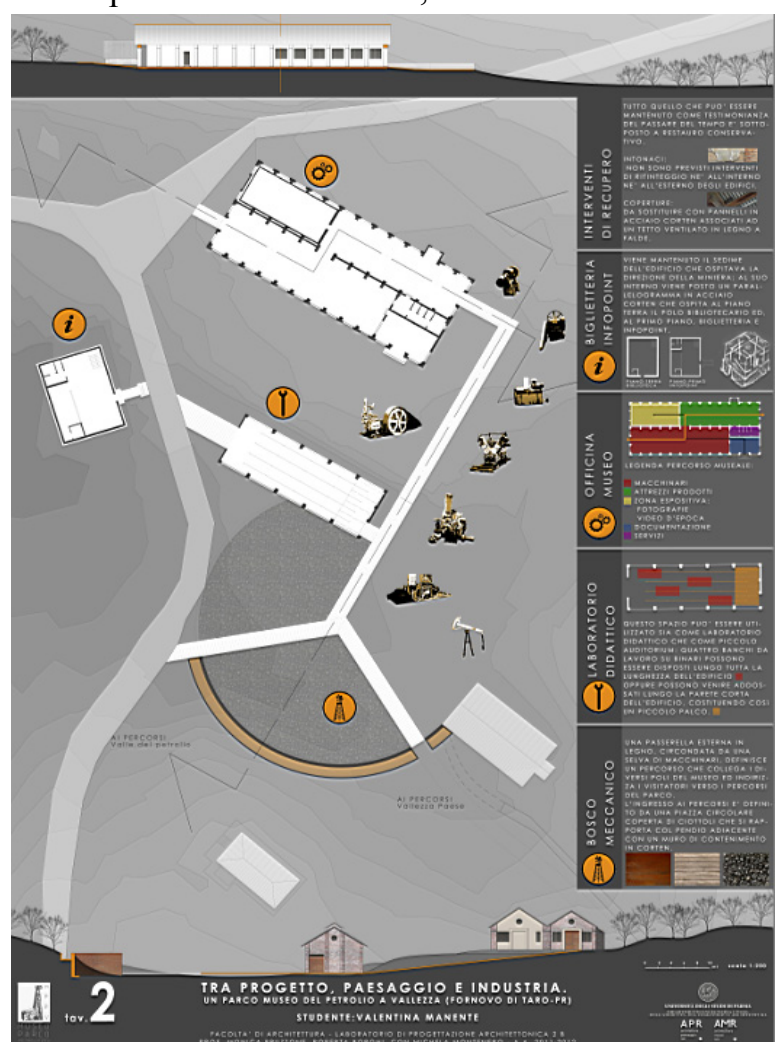

Fig. 6 A sample of the architectural design studio works. The museum park of Fornovo. A masterplan and the design of the cultural center in the Cantiere Respi, the heart of the former industrial site, by the student Valentina Manente (Architectural Design Studio 2-2013). 
from the Ministry, it is processing the project of a small pavilion or a multimedia installation by bringing in schools and public institutions in order to dissemitate the scientific culture connected with the oil and the memory of a lost cultural identity, and to trigger a virtuous cycle of rigeneration of this area, as well as of Fornovo di Taro, by increasing the value of an important industrial activity forgotten today and by giving a new centrality to a nice part of the Appenines very interesting but very little used today.

The new centrality should be able to generate a new complexity and liveability of the place, hosting different activities, planning diversified and easily accessible areas, and becoming, therefore, a strategic element for a wider part of the landscape.

\section{Conclusions}

Teaching about the design process and the architectural composition to young students in their first years of university can be a good opportunity to experiment a kind of teaching method based on three areas of teaching.

The first area is the theory. The main theoretical issues and the ideas of the architectural debate may be discussed with the students in order to communicate them the complexity of the architectural problems trough the centuries, and to stimulate the critical thinking. The second area is the technique. Only through the contamination between the architectural ideas and the materials, forms and techniques you can appreciate the discipline of architecture as a concrete fact and something three-dimensionally accomplished. But in addition to the theory and the technique, the discipline of architectural composition is also composed by the poetry. This third subject may be suggested or alluded or commented on by a teacher, who wants to communicate students the importance of this topic through the architectural debate and through every design process, but it is a matter quite delicate and fragile. As well can not certainly teach it, because it may became a part of each student's cultural baggage.

\section{Acknowledgments}

The authors would like to thank the MIUR (Italian Ministry of Research), the Municipality of Fornovo di Taro (Parma) and the Gas Plus Oil Company, for the financial support to the research. Also we would like to thank the AMR Research Group and the department Dicatea-University of Parma.

\section{References}

[1] Reconnecting the Design Research with Actual Demands of the Territory, AMR (Architecture Museums Network) and APR (Architecture Landscape Network), University of Parma, 2005.

[2] M. Bruzzone, L. Serpagli, Le radici anonime dell'abitare moderno, Ph.D. Thesis, University of Trento, Franco Angeli, Milano, 2012.

[3] R. Romano, C. Vivanti, I caratteri originali, Encyclopeda, Torino, 1972.

[4] G. Pagano, G. Daniel, Architettura Rurale Italiana, Quaderni della Triennale, Hoepli, Milano, 1936.

[5] P. Virilio, Crepuscular Dawn, Semiotext(e), NY, USA, 2002.

[6] L. Gambi, I valori storici dei quadri ambientali, in: Storia d'Italia, Einaudi, Torino, 1972.

[7] S. Settis, Paesaggio, Costituzione, Cemento, La battaglia per l'ambiente contro il degrado civile, Torino, 2010.

[8] U. Eco, Il museo del terzo millennio, Bilbao, June 25, 2001. 